\title{
Dynamics of persistent poverty in Italy at the beginning of the crisis
}

\author{
Lucia Coppola $^{*+}$ and Davide Di Laurea ${ }^{\dagger}$
}

\author{
* Correspondence: Icoppola@istat.it \\ ${ }^{\dagger}$ Equal contributors \\ ISTAT, Italian National Institute of \\ Statistics, Via Cesare Balbo 16, 00142 \\ Rome, Italy
}

\begin{abstract}
We propose an analysis of the persistent at risk of poverty (PARP) rate in Italy at the beginning of the Great Recession (2007-2010). Italy represents an interesting case study because it has one of the highest PARP rates in Europe, together with a weak labour market, an inadequate social security system, and a pronounced territorial dualism. EU statistics on income and living conditions (EU-SILC) longitudinal data are used. Logistic regression is applied to disentangle the relationship between household and main earner characteristics and the likelihood of being persistently poor. According to our results, male employees are more likely to hamper persistent poverty for their households; the opposite holds true for women as family breadwinner. Human capital endowment also shows a relevant role in preventing persistent poverty. The presence of children, instead, makes households more vulnerable. The South disadvantage slightly decreases at the beginning of the crisis. This is due to the worsening economic conditions in the North and Centre, affected to a wider extent by the economic downturn. The Italian welfare system appears ineffective in protecting worse-off households, and policies aimed at protecting employment, supporting women labour force participation, the elderly, and households with children would be needed.

Keywords: Poverty, Persistent poverty, Longitudinal data, EU-SILC, Italy

JEL classification: 132, C25
\end{abstract}

\section{Introduction}

The framework of Europe 2020, the European Union's growth strategy for the decade, shows policymakers' increasing interest in poverty issues: one of the five headline targets consists in reducing poverty or social exclusion, by lifting 20 million people out of poverty by 2020 (European Commission 2010). The definition of adequate policies, however, needs to rely not only on a measure of the level of poverty or social exclusion characterising a country but also on a clear knowledge of the underlying processes and trigger factors. For this reason, in the set of indicators used by the European Union (EU) to monitor social inclusion, the at risk of poverty (ARP) rate is complemented by the persistent at risk of poverty (PARP) rate that provides a more detailed picture of how consistently households experience poverty in time (Özdemir and Ward 2010). According to Eurostat, the ARP is the share of people with an equivalised disposable income below the ARP threshold, which is set at $60 \%$ of the national median equivalised disposable income. The PARP is then defined as the share of individuals at risk of poverty during the current year and at least two out of the three previous ones (Eurostat 2012).

(C) 2016 The Author(s). Open Access This article is distributed under the terms of the Creative Commons Attribution 4.0 International License (http://creativecommons.org/licenses/by/4.0/), which permits unrestricted use, distribution, and reproduction in any medium, provided you give appropriate credit to the original author(s) and the source, provide a link to the Creative Commons license, and indicate if changes were made. 
In the European context, Italy shows high levels of both ARP and PARP, respectively, 18.2 and $11.6 \%$ in 2010. They are 16.4 and $9.6 \%$ in the EU27 in the same year. Broadly, in Italy about $64 \%$ of the poor have been living in this condition persistently. Furthermore, Italy shows territorial dualism in terms of poverty or social exclusion (Istat 2011a), characterised by an extremely disadvantaged South, especially when persistent poverty is taken into account.

The causes of the Italian situation are a dual labour market combined with a scarcely supportive welfare system (Devicienti et al. 2014). As far the labour market is concerned, middle-aged employees in medium-large firms are the most protected category, because they have access to more stable jobs and may benefit of social protection insurance in case of need, while women and young workers typically get into short-term, low-paying jobs with limited access to social insurance schemes (Baldini and Ciani 2011). The welfare state, belonging to the so-called Southern-European or Mediterranean model (Esping-Andersen 1990; Gal 2010), does not provide universal or means-tested policies addressed to the most vulnerable households and strongly relies on family ties and intrafamilies support. Moreover, the persistence of division of roles by gender represents a weakness. The job loss or a decreased labour income by the breadwinner, typically a man, is not balanced by other household members' economic resources (Pasqua 2008; Figari et al. 2011).

The territorial dualism is associated with a stronger division of traditional roles and a weaker labour market, in terms of quality and quantity of labour supply, in the South. Lower women's labour force participation, higher unemployment rates, and lower earnings are observed (Istat 2011b, c).

This study is the first to shed light on persistent poverty, as defined in the framework of the EU indicators to monitor poverty and social exclusion, in the Italian context. Our results are especially relevant in a context characterised by a welfare system unable to let worse-off households escape poverty.

Particularly, we propose two specific research hypotheses: (i) households relying on income from dependent employment-more protected by social insurance-are expected to be associated with lower levels of persistent poverty, while a disadvantage for households whose main earner is a woman is expected because women traditionally play a secondary economic role in Italy; (ii) territorial differences are expected to increase in a period of crisis, because the possible causes of persistent poverty are more prevalent in the South and not tackled by the welfare system.

We refer to the Eurostat definition of the PARP and compare persistently poor individuals with the rest of the population, using logistic regression on the Italian EU statistics on income and living conditions (EU-SILC) longitudinal data. Household and main earner characteristics, as well as potential trigger events, are taken into account. This approach allows us to disentangle the role played by the possible determinants of poverty as a persistent experience.

Our results show that if the main source of income is from dependent employment, households are less likely to be persistently poor, while income from self-employment, pensions, or other sources let households worse off. The presence of a woman as the main earner of the household is associated with a higher risk of being persistently poor, as for the presence of children. Finally, the South shows much worse economic conditions than the rest of the country, even if such a disadvantage decreases at the 
beginning of the crisis, possibly because the economic downturn affected more production activities in the North and Centre.

Extremely limited and highly fragmented income maintenance schemes, together with low participation of women to the labour market, contribute to explain high levels of persistent poverty in Italy and territorial dualism. Policies aiming at protecting employment and supporting women labour force participation as well as households with children are needed to lift persistently poor households out of this condition.

This paper is structured as follows. The theoretical and Italian frameworks are illustrated, respectively, in the "Previous literature" and "The Italian picture and research hypotheses" sections. The data and method of the analysis are described in the "Data and methods" section. The main results are discussed in the "Results" section, and the "Conclusions" section concludes.

\section{Previous literature}

A vast literature studies poverty as a dynamic process, complementing the already wellestablished research on poverty as a static phenomenon. Different approaches have been applied, depending on the main focus of the research (see Aassve et al. 2006, for a survey). They range from the analysis of poverty patterns or profiles that investigates how permanent or recurrent poverty is, as well as the household and individual characteristics associated with a more consistent experience of being poor (Muffels et al. 2000; Gardiner and Hills 1999; Fouarge and Layte 2005); to poverty transitions that allow to identify characteristics and events that trigger poverty exits and prevent from poverty re-entries (Bane and Ellwood 1986; Jenkins 2000; Fouarge and Layte 2005; Aassve et al. 2006; Vandecasteele 2010; Andrioupoulou and Tsakloglou 2011a); to income dynamics through variance component models (Stevens 1999); and to counterfactual decomposition methods to assess the impact of socio-demographic and labour market country-specific characteristics on poverty (Dickens and Ellwood 2004; Damioli 2010).

In this paper, we focus on the PARP rate: it is based on the longitudinal component of the EU-SILC that follows individuals during 4 years. Persistently poor individuals are ARP at the current year and at least two out of the preceding three ones. Thus, our approach of analysis is close to that applied to poverty patterns or profiles (Muffels et al. 2000), but only two groups of individuals are taken into account: the persistent and non-persistent poor.

So far, not much attention has been devoted to an in-depth analysis of this indicator (Őzdemir and Ward 2010; Maître et al. 2011; Jenkins and Van Kerm, 2011; 2014). Jenkins and Van Kerm $(2011 ; 2014)$ claim that PARP can be predicted by ARP, through an existing near-linear relationship between these indicators. However, the analyses of the PARP indicator allow to shed a light on the most vulnerable households, which are not able to escape from the poverty condition. To this purpose, we take into account various poverty determinants, in terms of household characteristics and experienced events, besides those directly related to our main research hypotheses. To understand the effects of the current crisis, we also consider how the relationship between persistent poverty and its determinants evolves.

It is worth noting that the definition of income poverty is based on the equivalised disposable income that is the sum of all household and household members' income 
components, divided by the OECD equivalised household size. This definition relies on the assumption of income pooling, i.e. all household members have the same access to economic resources and the latter are used to achieve common household goals. Although such an assumption has been questioned (Donni and Chiappori 2011; Ponthieux 2013), it is still widely adopted in the study of poverty. Thus, poverty is defined at the household level, because all individuals belonging to the same household are expected to benefit from the same economic resources and they all are experiencing the same poverty status.

Several household characteristics contribute to determine poverty status, the likelihood to exit or re-enter it, and the persistence of such a condition. Particularly, the presence of children, the elderly, or other members unable to participate in the labour market are associated with a high level of persistence (Aassve et al. 2006; Devicienti et al. 2014). The household head is representative of the household economic condition. If he/she has a scarce earning capacity, because of a low level of education, and he/she is not well suited for the labour market, either very young or old, the household is more likely to live in poverty (Devicienti et al. 2014).

Apart from household characteristics, relative changes matter in keeping households persistently in poverty. Changes in household members' employment conditions and earning capacity indeed have been found to account for most of poverty transitions (Jarvis and Jenkins 1997; Muffels et al. 2000; McKernan and Ratcliffe 2005). Furthermore, household changes in terms of size and the household head, and demographic events as new births, union formation or dissolution, new household formation are also likely to trigger poverty transitions (McKernan and Ratcliffe 2005; Fouarge and Layte 2005; Aassve et al. 2006; Vandecasteele 2010).

Other research has been devoted to disentangle to what extent the persistence in poverty is determined by household members' characteristics (observed and unobserved), or to the previous experience of poverty itself. Evidence suggests that there is a direct effect from current to future poverty (Biewen 2009; Cappellari and Jenkins 2004; Aassve et al. 2006; Andrioupoulou and Tsakloglou 2011a, b). However, this issue is beyond the scope of our analysis.

\section{The Italian picture and research hypotheses}

Italy represents an interesting case study because it features one of the highest ARP rates in the European Union (see Fig. 1). In 2010, it was 18.2 \%, about 2 percentage points higher than the EU27 mean (16.4\%). Germany and the UK have lower rates (15.6 and $17.1 \%$, respectively), while poverty is higher in Spain (20.7\%). The PARP rate was $11.6 \%$ in Italy and $9.6 \%$ in EU27. The aforementioned countries show lower persistence (9.1\% in Germany, $7.4 \%$ in the UK, and $11 \%$ in Spain), and only four countries-Portugal, Bulgaria, Greece, and Romania-exhibit higher figures. By comparing the PARP with the ARP, a rough estimate ${ }^{1}$ of the share of individuals persistently poor among the poor can be provided. In 2010, the $63.7 \%$ of the poor have experienced this condition persistently in Italy, in comparison with $58.5 \%$ for the EU27 citizens, 43.3 \% in the UK, $53.1 \%$ in Spain, and $58.3 \%$ in Germany. Only six countries-Cyprus, Portugal, Bulgaria, Netherlands, Romania, and Greece-achieved higher ratios.

The experience of poverty is extremely heterogeneous over the national territory, the South showing the highest ARP (31\% in 2010). Lower income levels-the median 


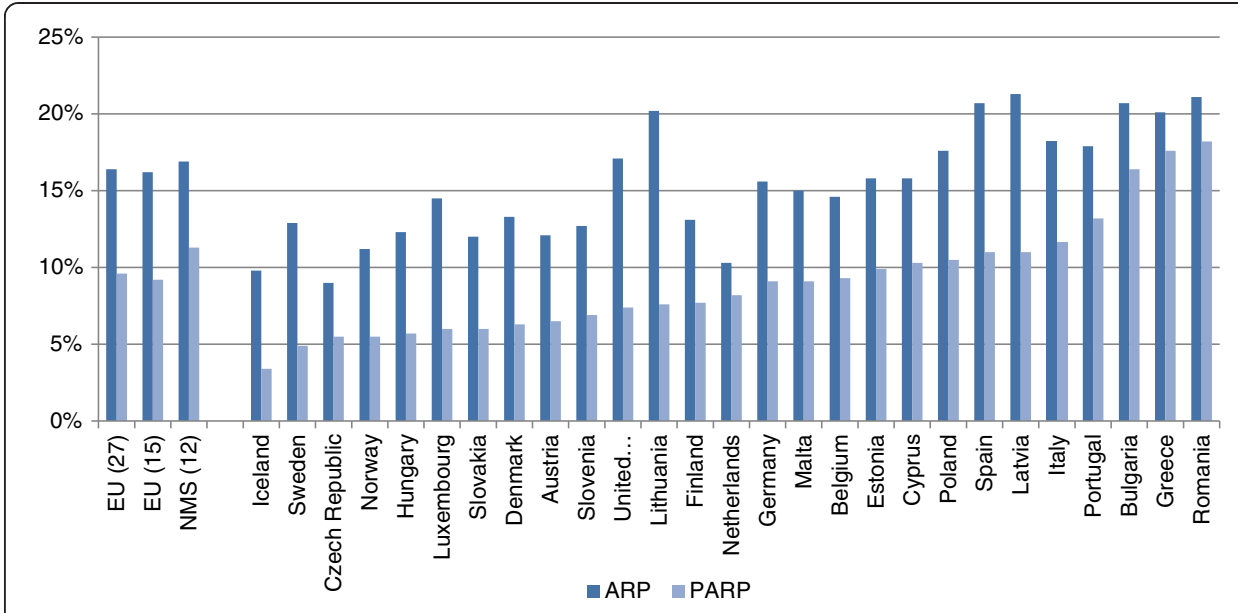

Fig. 1 At risk of poverty and persistent at risk of poverty rates by country, 2010. Source: Eurostat database

household income is about $75 \%$ of that in the North-go together with a higher proportion of severely deprived households: ${ }^{2} 12.9 \%$ in 2010, more than twice and three times than in the Centre and North (5.6 and $3.7 \%$, respectively) (Istat 2011a). Other relevant indicators of poverty, as absolute and relative poverty based on household consumptions, show that the South experiences much worse living conditions (Istat 2011d). The South witnesses also the highest level of $\operatorname{PARP}^{3}$ (22\% in 2010), three and four times higher than in the Centre and North, with 8.9 and $4.8 \%$, respectively (see Fig. 2). Moreover, the share of ARP individuals in the South, who have been persistently poor, reaches $71.2 \%$ in 2010 (in comparison with 63.5 and $47 \%$ in the Centre and North, respectively).

Earnings from work are the main source of income. So the functioning of the labour market plays a key role in determining the households' income distribution. Among workers, middle-aged employees in large industrial firms are more likely to hold permanent positions, and they rely on more stable economic resources. In contrast, women and the young typically have access to short-term, low-paying jobs only (Baldini and Ciani 2011).

Furthermore, the welfare system, very often assimilated to the Southern-European model (Esping-Andersen 1990), is scarcely supportive. Social interventions are not

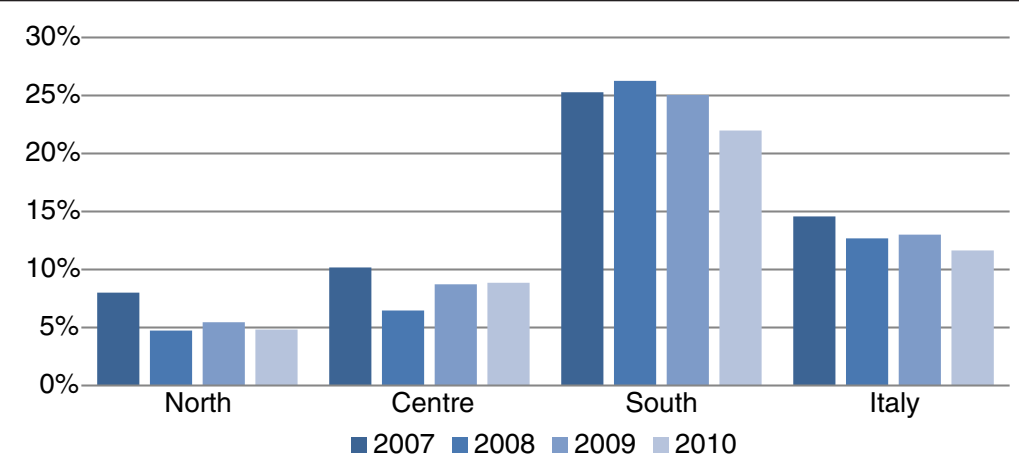

Fig. 2 Persistent at risk of poverty rate in Italy by geographical area, 2007-2010. Source: Authors' calculation on EU-SILC longitudinal UDB 
universally accessible but for health needs. There exists a limited and highly fragmented income maintenance system, based on different eligibility criteria and most recent earnings' replacement rates and addressing employees facing reduced work activities or unemployment. The prevalent scheme against the risk of underemployment or temporary unemployment for workers in medium-large industrial firms ("Cassa Integrazione Guadagni", CIG) is based on contributory history and accessible to employees not in managerial positions. CIG has an $80 \%$ replacement rate, and it is capped at about 1150 euros per month as a gross amount.

Similarly, unemployment insurance is available mostly for employees in large firms. It has a replacement rate between 40 and $60 \%$ with the same cap as above. It is provided for a period of 8 months, extended to 12 months for individuals aged 50 and over. There are no means-tested benefits for individuals not eligible or no longer eligible for unemployment benefits, and a system of minimum income level, independent on the employment status, is also absent. As a consequence, employees in small firms and self-employed and precarious workers are not protected (Figari et al. 2011; Baldini and Ciani 2011).

The rationale for this kind of welfare regime is largely based on the so-called breadwinner model, where a person's earnings are the primary source of support for the whole family. Generally speaking, adult men are expected to provide for their families; hence, they are typically the beneficiaries for social allowances. Besides, workers cannot rely on an adequate childcare system to reconcile work and family. The young do not benefit from any specific employment policies or economic support to start a business. The social sustainability of such a welfare framework is granted by informal processes. It strongly relies on family ties and intergenerational solidarity, leaving families alone in taking care for the young and elderly also in economic terms (Gal 2010).

Women's condition in the labour market is characterised by occupational segregation, lower returns from human capital, and lower wages (e.g. male and female full-time employees earn 1411 and 1257 euros per month, respectively, in 2010-see section 3.3.1 in Istat 2011c). In 2010, Italian women show lower employment rates than men (46.1 and $67.7 \%$, respectively), higher unemployment rates (9.7 vs $7.6 \%$ of men), and much higher inactivity rates (48.9 compared to $26.7 \%$ of men) (Istat 2011b). Furthermore, female employment rate in Italy is much lower than in Europe (58.2 \% in 2010) (Istat 2011c, chapter 3). Women's low labour market participation is strictly related to their being responsible for most of the family care (Istat 2011e). Such a gendered division of roles contributes to make families particularly vulnerable, because the job loss or a labour income decrease experienced by the main earner is barely cushioned by other household members' economic resources (Figari et al. 2011).

Finally, the pension system is far from generous: $44 \%$ of beneficiaries receive monthly benefits of less than 1000 euros gross (Istat 2013a).

The South-North gap in terms of economic well-being may be explained by relevant territorial differences in all the aspects so far discussed: the South is characterised by a wider gender specialisation, lower labour participation, and higher unemployment rates (Istat 2011b, c). In 2010, the employment rate is $43.9 \%$ in the South, while it is higher than $60 \%$ in the other regions (i.e. 65 and $61.5 \%$ in the North and Centre, respectively). Besides, the unemployment rate in the South is $13.4 \%$ (12 and $15.8 \%$ for men and women, respectively), while it is $5.9 \%$ in the North and $7.6 \%$ in the Centre. 
Inactivity rate also is much higher in the South than in the other regions (i.e. $49.2 \%$ in the South, $30.8 \%$ in the North, and $33.4 \%$ in the Centre) and achieves $63.7 \%$ for women (39.6 and $43.1 \%$ of women in the North and Centre, respectively).

Provided this picture of welfare system and labour market characteristics, our main research hypotheses concern the relationship between persistent poverty and (i) main earner income source and gender, to investigate the combined effects of a welfare state supporting mostly experienced employees and a gendered division of roles; (ii) the temporal evolution of territorial gap at the beginning of a period of crisis, to investigate territorial differences in terms of labour market and lack of adequate social protection policies.

Hypothesis I: Main earner income from dependent employment is expected to be associated with lower levels of persistent poverty. Employees are less at risk of losing their job and more likely to be eligible for income maintenance schemes, in case of need. A disadvantage for households whose main earner is a woman is expected because women traditionally play a secondary economic role.

Hypothesis II: Territorial differences are expected to increase in a period of crisis, because the possible determinants of persistent poverty are more prevalent in the South.

\section{Data and methods}

EU-SILC is the reference source for monitoring poverty and social exclusion in the EU. It relies on output harmonised national surveys: target variables are produced according to country-specific requirements, but common guidelines, procedures, concepts, and classifications are adopted to maximise comparability (European Commission 2003).

EU-SILC allows for both cross-sectional and longitudinal estimates. The longitudinal component, conceived for the study of poverty as a dynamic phenomenon, is based on a rotational sample design with four rotational groups, in Italy and most of the other countries. As shown in Table 1, every year a new sample is drawn and followed for 4 years. In a given year, the cross-sectional sample is made of households and household members belonging to four different panels (at the first, second, third, and fourth interview). At the moment of these analyses, four complete panels were available, covering the period preceding the crisis (2004-2007) and the subsequent period that includes the Great Recession beginning (2007-2010).

Italy applies a two-stage sampling design, where the first stage units are the municipalities and the second stage units are the households (Istat 2013b). Every year a sample of 8000 households is drawn and all household members belong to the sample.

Table 1 Rotational sample design of Italian EU-SILC

\begin{tabular}{|c|c|c|c|c|c|c|c|c|c|}
\hline Panel & 2004 & 2005 & 2006 & 2007 & 2008 & 2009 & 2010 & $\ldots$ & $\ldots$ \\
\hline 2004-2007 & W1 & W2 & W3 & W4 & & & & & \\
\hline $2005-2008$ & & W1 & W2 & W3 & W4 & & & & \\
\hline $2006-2009$ & & & W1 & W2 & W3 & W4 & & & \\
\hline $2007-2010$ & & & & W1 & W2 & W3 & W4 & & \\
\hline$\ldots$ & & & & & W1 & W2 & W3 & $\ldots$ & \\
\hline$\ldots$ & & & & & & W1 & W2 & $\ldots$ & $\ldots$ \\
\hline
\end{tabular}


Table 2 shows the number of households with a complete interview at the first wave of each panel (about 6200) and the corresponding number of household members (about 15,000). Differences in the sample size at the first wave are due to first wave nonresponse and household composition. Some of the sample individuals exit the panel temporarily or permanently, for non-response reasons or because they die or move abroad (see Eurostat 2010, for a detailed description of EU-SILC target population and following rules), and no information is available about their poverty condition. Being PARP defined as the share of ARP individuals during the last year, and at least two out of the three previous ones, it is computed only on individuals present in the panel during four consecutive years (the so-called balanced panels). In turn, all the individuals who exit the panel temporarily or permanently are dropped by the indicator computation and the analyses in the following.

As shown in Table 2, the balance panel size is about 10,000 individuals, i.e. $64.7 \%$ of the initial sample, with some small differences by panel. Likely, these individuals differ from those who exit the panel according to some characteristics of interest and related to poverty. If this is the case, estimates on the balance panel may be biased. For this reason, the EU-SILC user database provides longitudinal weights that in principle correct for potential bias introduced by the sample selection (Eurostat 2010). In Italy, longitudinal weights are provided at individual level and are adjusted for non-response, controlling for some characteristics (territorial domain, demographic size of the municipalities, number of household members, nationality, sex, age, education, and professional condition) (see Istat 2013b, for a detailed description of individual longitudinal weights).

The analyses we show in the following are based on the pooling of the four balanced samples, and normalised longitudinal weights are used to control for potential bias.

It is worth noting that, according to Eurostat, individuals are-by definition-certainly poor in the last year of observation, but not necessarily in the first one. Official indicator breakdowns, thus, are provided according to individual characteristics at the last year of observation. However, since in this paper we are interested in the determinants of poverty dynamics, and trigger events, characteristics at the first wave are controlled for, as well as some selected changes that occurred during the period of observation ${ }^{4}$.

We apply logistic regression to estimate the likelihood of being persistently poor: persistently poor individuals are compared to all other individuals, regardless of the pattern of poverty they experienced during the period of observation (i.e. never poor or poor only in some of the years).

Poverty is computed at the household level: if the household equivalised disposable income is below the poverty threshold (i.e. the $60 \%$ of the national median equivalised

Table 2 Longitudinal sample size of Italian EU-SILC by panel

\begin{tabular}{llllc}
\hline Panel & $\begin{array}{l}\text { Interviewed households } \\
\text { at wave 1 }\end{array}$ & $\begin{array}{l}\text { Interviewed individuals } \\
\text { at wave 1 (a) }\end{array}$ & $\begin{array}{l}\text { Balanced sample } \\
\text { size-individuals (b) }\end{array}$ & $\begin{array}{l}\text { Achieved sample } \\
\text { rate (b)/(a) } \times 100\end{array}$ \\
\hline 2004-2007 & 6259 & 15,822 & 10,466 & 66.1 \\
2005-2008 & 6194 & 15,805 & 10,148 & 64.2 \\
2006-2009 & 6167 & 15,389 & 9822 & 63.8 \\
2007-2010 & 6115 & 15,302 & 9903 & 64.7 \\
Total & 24,735 & 62,318 & 40,339 & 64.7 \\
\hline
\end{tabular}

Source: authors' calculation on EU-SILC longitudinal UDB 
disposable income), all the household members are poor. Coherently, also covariates are computed at the household level. In particular, we control for household-specific and main earner characteristics. The main earner is chosen because it is considered as the most representative of the household economic condition. However, the analyses are carried out at an individual level, for two main reasons. First, the PARP rate is computed as the share of individuals living in such a condition. Since we are interested in the analyses of the Europe 2020 indicator, as defined by Eurostat, we want to stay as close as possible to the original definition. Second, longitudinal weighs are provided at the individual level (i.e. they differ among the household members) because they correct for non-response at the individual level. Since all household members have the same characteristics, robust standard errors are provided.

Tables 3 and 4 show some descriptive statistics for the qualitative and quantitative covariates, respectively, by panel.

In order to verify our research hypotheses, we interact the main earner source of income (from dependent employment, self-employment, old-age pensions or other sources) with gender (hypothesis I) and the region of residence (North-Centre or South) with the year (hypothesis II). Other control variables are household-specific characteristics and their square: the number of earners, children ${ }^{5}$, and elderly ${ }^{6}$. Furthermore, main earner's characteristics are worth of consideration: sex, age (in classes: lower than $35,35-44,45-54,55-64,65$ or more), educational level (up to lower secondary education, secondary education, university degree or higher), and partner's educational level. We also control for the following life events: change in the household size and number of earners, new birth, new household formation, and change of the main earner.

The estimates of average marginal effects are also shown, to provide an easier interpretation of the model estimates (see Williams 2012, for a detailed description).

\section{Results}

Table 5 shows the logistic regression estimates for the pooled panels under analysis and average marginal effects. The coefficients of the main earner's source of income show that, as expected, households relying mostly on income from dependent employment are the least likely to be persistently poor. According to average marginal effects, if the main earner's income is from self-employment or pensions, the probability of being persistently poor is about 3 and $4 \%$ higher, respectively. Such a probability is about $9 \%$ higher when the household has to rely on other sources of income. Moreover, if the main earner is a woman, then the risk of living in a persistently poor household is $3 \%$ higher. Interaction terms between sex and sources of income are also significant, suggesting that female disadvantage is lower when she earns income from self-employment or other sources. Table 6 shows average marginal effects for women, by income source. We notice that female main earners have a 3.7 and $4.9 \%$ higher probability of being persistently poor when their main income source is, respectively, dependent employment or pensions. Thus, our first hypothesis seems to be confirmed by these estimates. In comparison with the households whose main earner is an employee, all other sources of income are either less stable and less protected by the welfare system in case of unemployment or income decrease, as in the case of self-employment 
Table 3 Covariates sample distributions by panel

\begin{tabular}{|c|c|c|c|c|c|c|c|c|c|c|}
\hline & \multicolumn{10}{|l|}{ Panel } \\
\hline & \multicolumn{2}{|c|}{ 2004-2007 } & \multicolumn{2}{|c|}{$2005-2008$} & \multicolumn{2}{|c|}{ 2006-2009 } & \multicolumn{2}{|c|}{ 2007-2010 } & \multicolumn{2}{|l|}{ Total } \\
\hline & $n$ & $\%$ & $n$ & $\%$ & $n$ & $\%$ & $n$ & $\%$ & $n$ & $\%$ \\
\hline \multicolumn{11}{|l|}{ Region } \\
\hline North & 4694 & 44.85 & 4219 & 41.57 & 4200 & 42.76 & 4220 & 42.61 & 17,333 & 42.97 \\
\hline Centre & 2325 & 22.21 & 2534 & 24.97 & 2224 & 22.64 & 2185 & 22.06 & 9268 & 22.98 \\
\hline South & 3447 & 32.94 & 3395 & 33.45 & 3398 & 34.60 & 3498 & 35.32 & 13,738 & 34.06 \\
\hline \multicolumn{11}{|l|}{ Sex } \\
\hline Male & 7768 & 74.22 & 7529 & 74.19 & 7110 & 72.39 & 7221 & 72.92 & 29,628 & 73.45 \\
\hline Female & 2698 & 25.78 & 2619 & 25.81 & 2712 & 27.61 & 2682 & 27.08 & 10,711 & 26.55 \\
\hline \multicolumn{11}{|l|}{ Source of income } \\
\hline Dep. empl. & 5371 & 51.32 & 5168 & 50.93 & 4922 & 50.11 & 5334 & 53.86 & 20,795 & 51.55 \\
\hline Self-empl. & 2079 & 19.86 & 2040 & 20.10 & 1900 & 19.34 & 1877 & 18.95 & 7896 & 19.57 \\
\hline Old-age pensions & 2664 & 25.45 & 2601 & 25.63 & 2621 & 26.68 & 2375 & 23.98 & 10,261 & 25.44 \\
\hline Other sources & 352 & 3.36 & 339 & 3.34 & 379 & 3.86 & 317 & 3.20 & 1387 & 3.44 \\
\hline \multicolumn{11}{|l|}{ Age } \\
\hline$<35$ & 1832 & 17.50 & 1661 & 16.37 & 1448 & 14.74 & 1496 & 15.11 & 6437 & 15.96 \\
\hline $35-44$ & 2697 & 25.77 & 2749 & 27.09 & 2618 & 26.65 & 2567 & 25.92 & 10,631 & 26.35 \\
\hline $45-54$ & 2410 & 23.03 & 2262 & 22.29 & 2267 & 23.08 & 2409 & 24.33 & 9348 & 23.17 \\
\hline $55-64$ & 1693 & 16.18 & 1557 & 15.34 & 1531 & 15.59 & 1560 & 15.75 & 6341 & 15.72 \\
\hline $65+$ & 1834 & 17.52 & 1919 & 18.91 & 1958 & 19.93 & 1871 & 18.89 & 7582 & 18.80 \\
\hline \multicolumn{11}{|l|}{ Educational level } \\
\hline Up to lower secondary & 5793 & 55.35 & 5408 & 53.29 & 5330 & 54.27 & 5236 & 52.87 & 21,767 & 53.96 \\
\hline Secondary & 3545 & 33.87 & 3643 & 35.90 & 3373 & 34.34 & 3458 & 34.92 & 14,019 & 34.75 \\
\hline University or higher & 1128 & 10.78 & 1097 & 10.81 & 1119 & 11.39 & 1209 & 12.21 & 4553 & 11.29 \\
\hline \multicolumn{11}{|l|}{ Partner's educational level } \\
\hline No partner & 2991 & 28.58 & 2738 & 26.98 & 2754 & 28.04 & 2666 & 26.92 & 11,149 & 27.64 \\
\hline Up to lower secondary & 4460 & 42.61 & 4158 & 40.97 & 4036 & 41.09 & 4001 & 40.40 & 16,655 & 41.29 \\
\hline Secondary & 2122 & 20.28 & 2307 & 22.73 & 2054 & 20.91 & 2328 & 23.51 & 8811 & 21.84 \\
\hline University or higher & 893 & 8.53 & 945 & 9.31 & 978 & 9.96 & 908 & 9.17 & 3724 & 9.23 \\
\hline \multicolumn{11}{|l|}{ Change in no. of earners } \\
\hline No change & 6020 & 57.52 & 5694 & 56.11 & 5666 & 57.69 & 5649 & 57.04 & 23,029 & 57.09 \\
\hline Gained only & 1983 & 18.95 & 1965 & 19.36 & 1872 & 19.06 & 1085 & 10.96 & 6905 & 17.12 \\
\hline Lost only & 1271 & 12.14 & 1057 & 10.42 & 916 & 9.33 & 1816 & 18.34 & 5060 & 12.54 \\
\hline Gained and lost & 1192 & 11.39 & 1432 & 14.11 & 1368 & 13.93 & 1353 & 13.66 & 5345 & 13.25 \\
\hline \multicolumn{11}{|l|}{ Change in household size } \\
\hline No & 8245 & 78.78 & 7969 & 78.53 & 8046 & 81.92 & 7972 & 80.50 & 32,232 & 79.90 \\
\hline Yes & 2221 & 21.22 & 2179 & 21.47 & 1776 & 18.08 & 1931 & 19.50 & 8107 & 20.10 \\
\hline \multicolumn{11}{|l|}{ New birth } \\
\hline No & 10,024 & 95.78 & 9742 & 96.00 & 9462 & 96.33 & 9572 & 96.66 & 38,800 & 96.18 \\
\hline Yes & 442 & 4.22 & 406 & 4.00 & 360 & 3.67 & 331 & 3.34 & 1539 & 3.82 \\
\hline \multicolumn{11}{|l|}{ New household } \\
\hline No & 10,214 & 97.59 & 9906 & 97.62 & 9641 & 98.16 & 9708 & 98.03 & 39,469 & 97.84 \\
\hline Yes & 252 & 2.41 & 242 & 2.38 & 181 & 1.84 & 195 & 1.97 & 870 & 2.16 \\
\hline
\end{tabular}


Table 3 Covariates sample distributions by panel (Continued)

\begin{tabular}{cllllllllll}
\hline Change in main earner & & & & & & & & & & \\
No & 7451 & 71.19 & 7211 & 71.06 & 7072 & 72.00 & 6943 & 70.11 & 28,677 & 71.09 \\
Yes & 3015 & 28.81 & 2937 & 28.94 & 2750 & 28.00 & 2960 & 29.89 & 11,662 & 28.91 \\
Total & 10,466 & 100.00 & 10,148 & 100.00 & 9822 & 100.00 & 9903 & 100.00 & 40,339 & 100.00 \\
\hline
\end{tabular}

Source: authors' calculation on EU-SILC longitudinal UDB

income, or unable to guarantee adequate economic well-being, as in the case of old-age pensions. The disadvantage of households is greater when the main earner is a woman and especially when her income is from dependent employment or pensions, possibly as a consequence of their lower wages.

As for the dynamic of PARP and territorial differences, the estimates show (i) a slight decrease in the probability of being persistently poor, which becomes $2.6 \%$ lower at the beginning of the crisis, and (ii) a clear disadvantage of the South, characterised by a probability of experiencing persistent poverty $12.9 \%$ higher than in the North. The Centre shows a higher risk of persistent poverty, but it is only about $3 \%$ higher than in the North. The interaction effect between year and region of residence shows a further disadvantage of the South in comparison with the North only before the crisis (20052008), while it becomes no longer significant in the following years. Table 6 shows the estimates of average marginal effects for the Centre and the South in comparison with the North, by year. Noticeably, the South shows a relevant decrease in the risk of being persistently poor at the beginning of the crisis, when the probability is $11.6 \%$ higher than in the North, while it was about $13 \%$ in the previous years. Thus, our second research hypothesis is not supported by the data: territorial dualism was wider before the crisis and decreased in 2010. This is likely to be due to worsening economic conditions in the North and Centre at the beginning of the crisis, implying a reduction in the disadvantage for the South. An explanation may be found in how the crisis spread over economic activities. Macro-level figures from National Accounts flows (Istat 2013c) show from 2009 (i.e. the income reference period corresponding to the 2010 EU-SILC survey data) a negative impact on household sector disposable income which is more pronounced in the Northern regions. This may be explained by a greater impact of the economic downturn on the export-led production and domestic demand in the North and Centre than in the South. Our results suggest that a similar dynamics holds on income distribution at a micro-level and on persistent poverty as well.

Other main earner and household characteristics and relative changes contribute to determine the likelihood of persistent poverty. Concerning the main earner

Table 4 Covariates sample means and standard deviation by panel

\begin{tabular}{|c|c|c|c|c|c|c|c|c|c|c|}
\hline & \multicolumn{8}{|l|}{ Panel } & & \\
\hline & \multicolumn{2}{|c|}{ 2004-2007 } & \multicolumn{2}{|c|}{ 2005-2008 } & \multicolumn{2}{|c|}{ 2006-2009 } & \multicolumn{2}{|c|}{ 2007-2010 } & \multicolumn{2}{|l|}{ Total } \\
\hline & Mean & St. dev. & Mean & St. dev. & Mean & St. dev. & Mean & St. dev. & Mean & St. dev. \\
\hline Age & 49.04 & 15.26 & 49.56 & 15.41 & 50.05 & 15.27 & 49.95 & 15.16 & 49.64 & 15.28 \\
\hline No. of earners & 2.01 & 0.91 & 1.96 & 0.87 & 1.92 & 0.87 & 2.12 & 1.01 & 2.00 & 0.92 \\
\hline No. of children & 0.73 & 0.94 & 0.77 & 0.97 & 0.76 & 0.99 & 0.75 & 0.97 & 0.75 & 0.97 \\
\hline No. of elder & 0.38 & 0.68 & 0.39 & 0.68 & 0.41 & 0.70 & 0.40 & 0.69 & 0.39 & 0.69 \\
\hline
\end{tabular}

Source: authors' calculation on EU-SILC longitudinal UDB 
Table 5 Logistic regression estimates of persistent at risk of poverty individuals and average marginal effects

\begin{tabular}{|c|c|c|c|c|c|c|}
\hline & Coef. & $\begin{array}{l}\text { Robust } \\
\text { std. err. }\end{array}$ & Sign. & $d y / d x$ & $\begin{array}{l}\text { Unconditional } \\
\text { std. err. }\end{array}$ & Sign. \\
\hline \multicolumn{7}{|l|}{ Sex (ref = Male) } \\
\hline Female & 0.4797 & 0.0889 & $* * *$ & 0.0328 & 0.0052 & $* * *$ \\
\hline \multicolumn{7}{|c|}{ Source of Income (ref = dependent employment) } \\
\hline Self-employment & 0.5252 & 0.0698 & $* * *$ & 0.0335 & 0.0053 & $* * *$ \\
\hline Old-age pensions & 0.5015 & 0.1012 & $* * *$ & 0.0421 & 0.0080 & $* * *$ \\
\hline Other income sources & 1.2550 & 0.1285 & $* * *$ & 0.0987 & 0.0115 & $* * *$ \\
\hline \multicolumn{7}{|l|}{ Year $($ ref $=2004-2007)$} \\
\hline $2005-2008$ & -0.3810 & 0.1163 & ** & -0.0201 & 0.0052 & $* * *$ \\
\hline $2006-2009$ & -0.3391 & 0.1139 & $* *$ & -0.0139 & 0.0051 & $* *$ \\
\hline $2007-2010$ & -0.4215 & 0.1193 & $* * *$ & -0.0258 & 0.0052 & $* * *$ \\
\hline \multicolumn{7}{|l|}{ Region (ref = North) } \\
\hline Centre & 0.4368 & 0.1230 & $* * *$ & 0.0320 & 0.0044 & $* * *$ \\
\hline South & 1.3135 & 0.0954 & $* * *$ & 0.1286 & 0.0043 & $* * *$ \\
\hline \multicolumn{7}{|l|}{ Age $($ ref $=<35$ years old $)$} \\
\hline $35-44$ & -0.6359 & 0.0773 & $* * *$ & -0.0521 & 0.0066 & $* * *$ \\
\hline $45-54$ & -0.3151 & 0.0798 & $* * *$ & -0.0277 & 0.0072 & $* * *$ \\
\hline $55-64$ & -0.3214 & 0.1036 & $* *$ & -0.0282 & 0.0091 & $* *$ \\
\hline $65+$ & -0.0711 & 0.1531 & & -0.0066 & 0.0141 & \\
\hline \multicolumn{7}{|c|}{ Educational level (ref = up to lower secondary) } \\
\hline Secondary & -0.9325 & 0.0577 & $* * *$ & -0.0764 & 0.0044 & $* * *$ \\
\hline University degree or higher & -2.2765 & 0.1588 & $* * *$ & -0.1323 & 0.0049 & $* * *$ \\
\hline \multicolumn{7}{|c|}{ Partner's educational level (ref = no partner) } \\
\hline Up to lower secondary & -0.0909 & 0.0682 & & -0.0082 & 0.0062 & \\
\hline Secondary & -0.6197 & 0.0886 & $* * *$ & -0.0492 & 0.0069 & $* * *$ \\
\hline University degree or higher & -1.2214 & 0.1439 & $* * *$ & -0.0835 & 0.0081 & $* * *$ \\
\hline \multicolumn{7}{|l|}{ Household composition } \\
\hline No. of earners & -1.7748 & 0.1106 & $* * *$ & -0.1475 & 0.0092 & $* * *$ \\
\hline No. of earners ${ }^{2}$ & 0.1691 & 0.0250 & $* * *$ & 0.0141 & 0.0021 & $* * *$ \\
\hline No. of children & 0.6897 & 0.0703 & * & 0.0573 & 0.0058 & $* * *$ \\
\hline No. of children ${ }^{2}$ & -0.0071 & 0.0191 & & -0.0006 & 0.0016 & \\
\hline No. of elder & 0.0125 & 0.1682 & & 0.0010 & 0.0140 & \\
\hline No. of elder ${ }^{2}$ & 0.1132 & 0.0644 & & 0.0094 & 0.0054 & \\
\hline \multicolumn{7}{|l|}{ Change in no. of earners } \\
\hline Gained only & -0.2324 & 0.0616 & $* * *$ & -0.0166 & 0.0043 & $* * *$ \\
\hline Lost only & 1.2421 & 0.0833 & $* * *$ & 0.1227 & 0.0094 & $* * *$ \\
\hline Gained and lost & 0.8210 & 0.0679 & $* * *$ & 0.0747 & 0.0068 & $* * *$ \\
\hline \multicolumn{7}{|l|}{ Other household changes } \\
\hline Change in household size (ref $=$ no) & -0.3946 & 0.0803 & $* * *$ & -0.0310 & 0.0059 & $* * *$ \\
\hline New birth $($ ref $=$ no $)$ & 0.4166 & 0.1359 & $* *$ & 0.0377 & 0.0133 & $* *$ \\
\hline New household $(r e f=$ no) & -0.2356 & 0.1774 & & -0.0186 & 0.0132 & \\
\hline Change in main earner $(r e f=$ no) & 0.2356 & 0.0592 & $* * *$ & 0.0201 & 0.0052 & $* * *$ \\
\hline
\end{tabular}


Table 5 Logistic regression estimates of persistent at risk of poverty individuals and average marginal effects (Continued)

\begin{tabular}{llll}
\hline Sex and source of income & & & \\
Female, self-employment & -0.3494 & 0.1485 & $*$ \\
Female, old-age pensions & 0.0257 & 0.1168 & \\
Female, other income sources & -0.6693 & 0.2024 & $* *$ \\
Year and region & & & \\
2005-2008, Centre & -0.1307 & 0.1819 & \\
2006-2009, Centre & 0.2806 & 0.1421
\end{tabular} *

Source: authors' calculation on EU-SILC longitudinal UDB ${ }^{* * *} p<0.001 ;{ }^{* *} p<0.01 ;{ }^{*} p<0.05$

characteristics, age is relevant: as expected, households whose main earner is middleaged are better off. In comparison with young main earners (less than 35 years old), those aged between 35 and 44 show a probability of about $5 \%$ lower to be persistently poor, and those aged $45-54$ or 55-64 about $2.8 \%$ lower. In contrast, elder main earners do not significantly differ from the young. Thus, when the main earner is either young or old, the household is more likely to be persistently poor. The former are less likely to have achieved a job position that guarantees economic stability or the

Table 6 Average marginal effects, by combination of some specific characteristics

\begin{tabular}{|c|c|c|c|}
\hline & $d y / d x$ & Unconditional std. err. & Sign \\
\hline \multicolumn{4}{|l|}{ Female } \\
\hline Dependent employment & 0.0366 & 0.0072 & \multirow[t]{2}{*}{$* * *$} \\
\hline Self-employment & 0.0117 & 0.0115 & \\
\hline Old-age pensions & 0.0489 & 0.0087 & \multirow[t]{2}{*}{$* * *$} \\
\hline Other income sources & -0.0215 & 0.0209 & \\
\hline \multicolumn{4}{|l|}{ Centre } \\
\hline 2004-2007 & 0.0329 & 0.0096 & $* *$ \\
\hline $2005-2008$ & 0.0175 & 0.0078 & * \\
\hline $2006-2009$ & 0.0350 & 0.0088 & $* * *$ \\
\hline $2007-2010$ & 0.0430 & 0.0090 & $* * *$ \\
\hline \multicolumn{4}{|l|}{ South } \\
\hline 2004-2007 & 0.1254 & 0.0088 & $* * *$ \\
\hline $2005-2008$ & 0.1353 & 0.0085 & $* * *$ \\
\hline 2006-2009 & 0.1383 & 0.0081 & $* * *$ \\
\hline $2007-2010$ & 0.1155 & 0.0081 & $* * *$ \\
\hline
\end{tabular}

Source: authors' calculation on EU-SILC longitudinal UDB ${ }^{* * *} p<0.001 ;{ }^{* *} p<0.01 ;{ }^{*} p<0.05$ 
requisites to access social protection benefits. The latter are recipients of a relatively lower and stagnant income.

Main earner's educational achievement is strongly associated with persistent poverty. Highly educated main earners represent households with a much lower risk of being persistently poor (i.e. those with secondary and tertiary education have, respectively, a 7.6 and $13.2 \%$ lower probability than those with lower secondary education). Also the presence of a partner, if highly educated, is relevant. In comparison with single main earners, if he/she has a partner with secondary or tertiary education, the household experiences a risk of being persistently poor, respectively, 4.9 and $8.3 \%$ lower. The presence of a partner with low education does not make any significant difference.

The household composition is also relevant. The risk of being persistently poor increases linearly with the number of children, representing a source of additional costs and needs, as argued, not supported by ad hoc policies. The higher the number of earners, the lower the likelihood of being persistently poor, even if at a decreasing rate. The presence of the elderly, instead, is not associated with a higher risk of experiencing poverty persistently.

The changes that occurred in the households over the period of observation are also related to persistent poverty. Among the events accounted for, the change in number of earners has a preeminent role. By comparing the number of earners in different years, we distinguish among (i) households with the same number of earners in the whole period of observation, (ii) households that have only lost earners (one or more), (iii) households that have only gained earners (one or more), and (iv) households that have both lost and gained earners. The estimates show a slight comparative advantage for those having acquired new earners (showing a $1.7 \%$ lower probability in comparison with households with the same number of earners). In contrast, those who have only lost earners, or both lost and gained earners, respectively, show a 12.3 and $7.5 \%$ higher probability of being persistently poor. Earner loss reduces household economic resources, and it is not balanced by the concurrent gain of other earners in the same period.

Any change in the household size (either an increase or a decrease) is associated with a slightly lower risk of persistent poverty, as is the case for a new household formation. This could be the result of selection: possibly only less vulnerable households engage in structural changes. A new birth, instead, seems to elude this mechanism and is associated with a $3.8 \%$ higher probability of being persistently poor. If the main earner changes, the household is only $0.5 \%$ more likely to be persistently poor. A nonsignificant difference is estimated for new households.

\section{Conclusions}

We analyse the PARP rate in Italy between 2007 and 2010. This measure of poverty is one of the main indicators used by the European Commission to monitor poverty and social exclusion in the European Union and the only one representing poverty as a dynamic phenomenon. This can help shedding light on the possible determinants of persistent poverty.

Among the poor, the persistently poor are the most vulnerable, because they rarely quit this condition and, even if they do, they are more likely to face other spells of 
poverty in the future. Thus, policies aiming at reducing poverty, as recommended by the Europe 2020 EU's growth strategy, should focus on this group.

Italy represents an interesting case study in the EU being exposed to one of the largest and most persistent poverty rate. Moreover, Italy is characterised by a dramatic territorial dualism, with the South experiencing extremely worse living conditions than the rest of the country.

A weak labour market and an inadequate social protection system characterise this landscape. In particular, the young and women are less favourite in the labour market. The former typically have access to less stable and worse paid jobs. The latter can hardly reconcile family tasks with work. Among workers, only specific categories are supported in case of job loss or income decrease, particularly middle-aged employees in medium-large size firms. This situation is worsened by a welfare system that relies heavily on family ties and that does not address the needs of worse-off households through either universal or means-tested policies. The territorial dualism in terms of persistent poverty is partly explained by an even less favourable labour market in the South, characterised by higher unemployment rates, combined with a more traditional division of roles and the subsequent lower women's commitment to paid work.

In this framework, we focus on the interaction between the Italian labour market and welfare characteristics in shaping the likelihood of being persistently poor, according to households' main earner source of income and gender, as well as the temporal evolution of the territorial dualism during the crisis. As expected, households whose main earner is a recipient of income from dependent employment show lower levels of persistent poverty, because social interventions are tailored in order to protect (part of) them: they are less likely to lose their job and, if they do, they may be eligible to receive some unemployment insurance. In contrast, self-employed and retirees face worse economic conditions. The former cannot rely on ad hoc policies in case of job loss, earning decrease, or reduced economic activity; the latter mostly receive lower and stagnant retirement benefits. When the main earner is a woman, the household is more likely persistently poor because women traditionally play a secondary economic role in Italy.

As for the territorial dualism, the South disadvantage decreases at the beginning of the crisis (2010). A possible explanation is the worsening economic conditions experienced at the beginning of the crisis by the North and Centre, which were affected to a wider extent by the economic downturn.

Other main earner and household characteristics are relevant in determining the risk of being persistently poor. Particularly worth of consideration is human capital endowment that shows a key role in preventing persistent poverty. The presence of children, instead, makes households more vulnerable. As foreseen, the more the earners in the household, the lower is the risk of persistent poverty. The loss of any earner determines a higher risk of poverty persistence and is not balanced by the gain of other earners.

According to our results, the Italian welfare regime appears inadequate to protect worse-off households from the persistent experience of poverty. Policies aiming to promote employment, new entries or re-entries into the labour market, and women labour force participation are appropriate strategies to let households escape from poverty. Ad hoc policies should focus also on the elderly and households with children.

The evidence discussed in this paper is certainly not exhaustive. However, the short period of observation of individuals in EU-SILC hampers the explanatory power of 
other more sophisticated methods of analysis (Eiffe and Till 2013). We plan to investigate poverty transitions and take explicitly into account poverty duration, as well as the exact timing and pattern of changes in the household characteristics, when richer data will be available.

\section{Endnotes}

${ }^{1}$ The ARP and PARP rates are estimated on the EU-SILC cross-sectional and longitudinal samples, respectively (the latter is a sub-sample of the former).

${ }^{2}$ The severe material deprivation refers to a state of economic strain and the inability to afford four or more of the following items: unexpected expenses; a 1-week annual holiday away from home; a meal involving meat, chicken, or fish every second day; the adequate heating of a dwelling; a washing machine; a coloured television, telephone, or car; and payment arrears (mortgage or rent, utility bills, hire purchase instalments or other loan payments).

${ }^{3}$ The PARP rate in year $t$ is computed on individuals interviewed in year $t$ and the previous 3 years (e.g. PARP 2007 is computed on individuals belonging to the 20042007 panel).

${ }^{4}$ If characteristics at last year of observation are controlled for, trigger events cannot be included in the model, because their effects would already be implied in the characteristics as observed in the last wave (e.g. the number of children in the last year of observation already includes the possible effect of a birth occurred during the period of observation). However, models with household and main earner characteristics at last wave have also been estimated: results appear mostly consistent and are available upon request.

${ }^{5}$ All household members less than 18 years old are defined as children.

${ }^{6}$ All household members aged 65 years or more are defined as elderly.

Competing interests

The authors declare that they have no competing interests.

\section{Authors' contributions}

LC conceived of the study, performed the statistical analysis, participated in the interpretation of the data, and drafted the manuscript. DDL participated to conceive of the study, contributed to perform the statistical analysis and to the interpretation of the data, and drafted the manuscript. All authors read and approved the final manuscript.

\section{Acknowledgements}

We would like to thank Leen Vandecasteele, Richard Layte, and two anonymous referees for their useful suggestions and comments and Franz F. Eiffe, Matthias Till, Riccardo Di Cecio, and Stefano Gerosa for their support.

\section{Disclaimer}

The contents of this article do not reflect the official opinion of the Institution the authors belong to. Responsibility for the views expressed therein lies entirely with the authors.

Received: 13 May 2015 Accepted: 12 February 2016

Published online: 14 July 2016

\section{References}

Aassve, A, Burgess, S, Dickson, M, Propper, C. (2006). Modelling poverty by non modelling poverty: an application of a simultaneous hazards approach to UK. CASE Discussion Paper Series, 106, Centre for Analysis of Social Exclusion, London School of Economics, London. http://sticerd.lse.ac.uk/dps/case/cp/CASEpaper106. pdf. Accessed 23 Feb 2016

Andrioupoulou, E, Tsakloglou, P. (2011a). The determinants of poverty transitions in Europe and the role of duration dependence. MPRA Paper 30659. https://mpra.ub.uni-muenchen.de/30659/1/MPRA_paper_30659.pdf. Accessed 23 Feb 2016

Andrioupoulou, E, Tsakloglou, P. (2011b). Once poor, always poor? Do initial conditions matter? Evidence from the ECHP. IZA Discussion Paper Series, 5971. http://ftp.iza.org/dp5971.pdf. Accessed 23 Feb 2016

Baldini, M., \& Ciani, E. (2011). Inequality and poverty during the Recession in Italy. Politica Economica, 3, $297-322$. 
Bane, M. J., \& Ellwood, D. T. (1986). Slipping into and out of poverty: the dynamics of spells. Journal of Human Resources, 21(1), 1-23.

Biewen, M. (2009). Measuring state dependence in individual poverty histories when there is feedback to employment status and household composition. Journal of Applied Econometrics, 24(7), 1095-1116.

Cappellari, L., \& Jenkins, S. P. (2004). Modelling low income transitions. Journal of Applied Econometrics, 19, 593-610.

Damioli, G. (2010). How and why dynamics of poverty differ across European countries. $31^{\text {st }}$ general conference of the International Association for Research in Income and Wealth, St. Gallen, Switzerland. http://www.lariw.org/papers/ 2010/6dDamioli.pdf. Accessed 23 Feb 2016

Devicienti, F., Gualtieri, V., \& Rossi, M. (2014). The persistence of income poverty and lifestyle deprivation: evidence from Italy. Bulletin of Economic Research, 66(3), 246-278.

Dickens, R, Ellwood, DT. (2004). Whither poverty in Great Britain and the United States? The determinants of changing poverty and whether work will work. In D. Card et al. (Eds.), Seeking a Premier Economy: The Economic Effects of British Economic Reforms, 1980-2000 (pp. 313-370). Chicago: the University of Chicago Press.

Donni, O., Chiappori, PA (2011). Non-unitary models of household behaviour: a survey. In JA Molina (Ed.), Household Economic Behaviours (pp. 1-40). International Series on Consumer Science. Springer, New York.

Eiffe, FF, Till, M. (2013). The longitudinal component of Eu-Silc: still underused? NetSilc2 Working Paper, 1/2013. http://www.statistik.at/wcm/idc/idcplg?ldcService=GET_PDF_FILE\&dDocName=080741. Accessed 23 Feb 2016

Esping-Andersen, G. (1990). The three worlds of welfare capitalism. Princeton: Princeton University Press.

European Commission (2003). Framework regulation, 1177/2003. http://eur-lex.europa.eu/LexUriServ/LexUriServ. do?uri=OJ:L:2003:165:0001:0009:EN:PDF. Accessed 23 Feb 2016

European Commission (2010). Europe 2020, a strategy for smart, sustainable and inclusive growth, COM(2010) 2020 final. http://eur-lex.europa.eu/LexUriServ/LexUriServ.do?uri=COM:2010:2020:FIN:EN:PDF. Accessed 23 Feb 2016

Eurostat (2010). Description of target variables: cross-sectional and longitudinal (operation 2010). https://circabc.europa. eu/w/browse/95a7b6bc-33ea-494c-a865-bf192ed23fea. Accessed 23 Feb 2016

Eurostat (2012). Working paper with the description of the 'income and living conditions dataset', Eu-Silc: Methodological studies and publications. Accessed 23 Feb 2016

Figari, F., Salvatori, A., \& Sutherland, H. (2011). Economic downturn and stress testing European welfare system. Research in Labour Economics, 32, 257-286.

Fouarge, D., \& Layte, R. (2005). Welfare regimes and poverty dynamics: the duration and recurrence of poverty spells in Europe. Journal of Social Policy, 34(3), 407-426.

Gal, J. (2010). Is there an extended family of Mediterranean welfare states? Journal of European Social Policy, 20(4), 283-300.

Gardiner, K., \& Hills, J. (1999). Policy implication of new data on income mobility. The Economic Journal, 109(453), 91-111.

Istat (2011a). Reddito e Condizioni di Vita. Statistiche Report. http://www.istat.it/it/archivio/48985. Accessed 23 Feb 2016.

Istat (2011b). Occupati e Disoccupati. Statistiche Flash. http://www.istat.it/it/archivio/21875. Accessed 23 Feb 2016

Istat (2011c). Capitolo 3. Mercato del lavoro più debole, minore qualità dell'occupazione. Rapporto Annuale 2010. http://www3.istat.it/dati/catalogo/20110523_00/. Accessed 23 Feb 2016

Istat (2011d). La povertà in Italia. Statistiche Report. http://www.istat.it/it/archivio/33524. Accessed 23 Feb 2016

Istat (2011e). Conciliazione tra Lavoro e Famiglia. Statistiche Report. http://www.istat.it/it/archivio/48912. Accessed 23 Feb 2016

Istat (2013a). Trattamenti pensionistici e beneficiari. Statistiche Report. http://www.istat.it/it/archivio/87850. Accessed 23 Feb 2016

Istat (2013b). 2010 final quality report IT. EU-SILC technical documentation. https://circabc.europa.eu/w/browse/ fa32c5d4-c36e-4aac-954c-d9972e73550a. Accessed 23 Feb 2016

Istat (2013c). II reddito disponibile delle famiglie nelle regioni italiane. Statistiche Report. http://www.istat.it/it/ archivio/81454. Accessed 23 Feb 2016

Jarvis, S., \& Jenkins, S. P. (1997). Low income dynamics in 1990s Britain. Fiscal Studies, 18(2), 123-142.

Jenkins, S. P. (2000). Modelling household income dynamics. Journal of Population Economics, 13, 529-567.

Jenkins, S.P., \& Van Kerm, P. (2011). Patterns of persistent poverty: evidence from EU-SILC. ISER Working Paper Series 2011-30, Institute for Social and Economic Research.

Jenkins, S.P., \& Van Kerm, P. (2014). The Relationship Between EU Indicators of Persistent and Current Poverty. Social Indicators Research- An International and Interdisciplinary Journal for Quality-of-Life Measurement, 116, 611-638.

Maitre, B, Russell, H, Watson, D. (2011). Persistent at-risk-of-poverty in Ireland: an analysis of the Survey on Income and Living Conditions 2005-2008. Social Inclusion Technical Paper,1, Department of Social Protection, Dublin, Ireland. http://www.socialinclusion.ie/documents/2011-11-24_webPersistentAtRisk.pdf. Accessed 23 Feb 2016

McKernan, S. M., \& Ratcliffe, C. (2005). Events that trigger poverty entries and exits. Social Science Quarterly, 86, 1146-1169.

Muffels, R., Fouarge, D., \& Dekker, R. (2000). Longitudinal poverty and income inequality: a comparative panel study for the Netherlands, Germany and the UK. MPRA paper 13298. Germany: University Library of Munich.

Özdemir, E, Ward, T. (2010). The persistent risk of poverty. Research note, 7/2010, European Commission. http://ec. europa.eu/social/BlobServlet?docld=6725\&langld=en. Accessed 23 Feb 2016

Pasqua, S. (2008). Wives' work and income contribution in European countries. European Journal of Comparative Economics, 5(2), 157-186.

Ponthieux, S. (2013). Income pooling and equal sharing within the household—what can we learn from the 2010 Eu-Silc module? Eurostat methodologies and working papers, European Union. http://ec.europa.eu/eurostat/documents/ 3888793/5857781/KS-RA-13-013-EN.PDF. Accessed 23 Feb 2016

Stevens, A. H. (1999). Climbing out of poverty, falling back in. Measuring the persistence of poverty over multiple spells. Journal of Human Resources, 34(3), 557-588.

Vandecasteele, L. (2010). Poverty trajectories after risky life course events in different European welfare regimes. European Societies, 12(2), 257-278.

Williams, R. (2012). Using the margins command to estimate and interpret adjusted predictions and marginal effects. The Stata Journal, 12(2), 308-331. 